\title{
Editorial on the special issue "Private Life Choices, Employment and Health"
}

\section{Rainer Unger, Alexander Schulze}

The health conditions of the German population have been subject to significant changes in the past. Within the last forty years, for example, the life expectancy at birth of both men and women reported by the German Federal Statistical Office rose by more than eight years. In recent years, chances of survival in the middle and old ages were responsible for the increase in life expectancy. In this respect - and to an extent never seen before - it is nowadays possible to spend one's lifetime actively within the family and productively on the labour market.

However, in times of a shrinking population, changes of the conditions on the labour market and new arrangements of private life choices, this positive development also presents us with new challenges. Thus, the improved health conditions have been accompanied by numerous social changes, which might counteract the benefits (e.g. longer working lifetime, erosion of traditional family structures). Moreover, up until today not all population groups can benefit equally from the health progress (health inequalities). Therefore, this special issue has its focus on recent developments in the context of the topics private life choices, employment and health and will discuss their interdependencies (family and employment) regarding the development of health inequalities.

The first two articles both deal with issues regarding the relationship between employment and health with a particular focus on the aspect of social change. In their article "Can We Really (All) Work Longer? Trends in Healthy Life Expectancy According to Social Stratum in Germany", Rainer Schulze and Alexander Unger ask the question whether healthy life years have increased along with the increase in life expectancy and whether all population groups (i.e. three different income groups and three different educational backgrounds) equally benefit from this positive development. As a basis for their empirical analyses, they used the Socio-Economic Panel (SOEP), as its long observation period allows analyses spanning almost three decades. Thus, after a comparison of the years 1989, 1999 and 2009, the authors were able to show that healthy life years have increased in both men and women. However, although all social classes benefit from this gain in healthy life years, the study also showed that regarding healthy life expectancy, social differences have increased over this period of time. This means that health inequalities between different social classes are rising. With these results of life chances that turn out to be so unequally distributed when looking at social class, the initial idea of a longer working life time for all cannot be followed through. The results rather suggest a more flexible handling of the standard retirement age. 
The second article by Monika Jungbauer-Gans and Gerhard Krug "Changes in Employed People's Health Satisfaction" also uses the long observation period of the SOEP from 1985 to 2009 . Contrary to the first article, which primarily focused on a description of health conditions over a certain time period and sorted by social class, these two authors examine the causes of changes in health conditions, more precisely whether individual changes in health during this time period can be traced back to changing employment conditions (e.g. fixed-term contracts, changes in pay, change in working hours, job security, assessment of the economic situation, company size, autonomy in job assignments). In order to determine the impact of the employment situation in explaining the change in health satisfaction, the Blinder/ Oaxaca decomposition was used. On the one hand, their results indicate that especially in Western Germany, a significant proportion of the decrease in health satisfaction can be explained by the proportional increase in precarious employment relationships or with an increase in worries about the economical situation. On the other hand, however, the negative correlation between job security and health satisfaction has increased over the examined time period. For future research, it therefore seems worthwhile to investigate how future massive cuts on the labour market will affect subjective health.

The next two articles deal with the influence of couples' living arrangements on health. Are there, for example, favourable constellations of partners living together? The majority of previous research merely differentiated between health behaviour of married versus unmarried couples. The article of Thomas Klein, Ingmar Rapp and Björn Schneider - "The Influence of Couples' Living Arrangements on Smoking Habits and Body Weight" - asks the question whether the changes in couples' living arrangements might be an explaining factor of the changes in health behaviour of the population. For their analyses, they used the Partnermarktsurvey 2009, in which $n=2002$ individuals aged $16-55$ years were retrospectively asked about their relationship biography and their health behaviour. One of their results is that especially in marriages - and only in those where both partners live together - the spouses smoke significantly less often but at the same time have a significantly higher bodymass-index (BMI) than in all other couples' living arrangements. Smoking cessation is also linked to the shared household of married couples, which indicates that the protection effect is based on social control and support. Furthermore, there is also evidence of adaptation processes regarding smoking behaviour. Thus, smoking cessation is more likely when the partner never smoked or has given up smoking. In addition, however, there is also a tendency to conformity in smoking behaviour at the beginning of a relationship. The weight gain of spouses in the course of marriage, on the contrary, can be attributed to the longer relationship duration of married couples.

The article by Hilke Brockmann - "Unhealthy conditions? A longitudinal analysis of the health of children in one- and two-parent households" - focuses primarily on the question whether the change in private life choices, especially increasing divorce rates, have an impact on the health of younger children. She also uses data from the SOEP, which has been providing biographical information of mothers and their newborns as well as small children since 2002. By using panel models with 
fixed effects, she controls for possible selection processes, so that a causal explanation becomes possible. Some of the results are that the children of non-married individuals have a lower birth weight (even when controlling for additional factors) as well as that a divorce does have long-lasting health-related consequences, as reflected for example in a deviation of the $\mathrm{BMI}$, whereas sociodemographic characteristics of the household have no influence. It could also be shown that the mental constitution of the mother is far more important for the healthy well-being of the child than financial resources.

In the final article "The Influence of Regional Social Inequality and Labour Market

Characteristics on Health", which was written by Christiane Gross und Peter Kriwy, the authors examine the question to what extent causal mechanisms of the the place of residence have an effect on the individual health status. They used the SOEP data base of the year 2006 and additionally drew on regional information on the basis of the regional units (Raumordnungsregionen) of the Microcensus 2005, which were then analysed using multilevel models. Here, the influence of causal mechanisms in the form of inequality and level effects could also be shown when controlling for individual socio-economic influences. For example, in educationally disparate regions, members of less-educated groups have particularly low and members of well-educated groups particularly high health chances (especially in women). A high unemployment rate, however, increases the negative effect of individual unemployment on health (especially in men).

In summary, it can be stated that the articles have mainly shown that a highly differentiated argumentation is required in order to depict the complex correlations between social characteristics and health. This often puts high requirements on the available data. Some of the questions posed, such as the one asking for the change in healthy life expectancy or for the impact of the employment situation on health, use the advantages of the long observation period of the SOEP. Other questions use the innovations such data are affiliated with, as in the article which uses the information of interviewed mothers about their newborns and small children regarding the influence of divorce on various health variables. Furthermore, these data also offer the possibility to investigate regional aspects, as for example when looking at the influence of regional inequality structures on health. Other studies, which for example ask for the correlation between couples' living arrangements and health show that retrospectively collect relationship biographies (as in the case of the Partnermarktsurvey 2009) are also suited and offer some advantages, such as when capturing couples living apart.

Dr. Rainer Unger ( $₫)$. Universität Bremen, Zentrum für Sozialpolitik, 28359 Bremen, Germany. E-Mail: r.unger@zes.uni-bremen.de URL: http://www.zes.uni-bremen.de/das-zentrum/organisation/mitglieder/rainer-unger/

Dr. Alexander Schulze. Johannes Gutenberg-Universität Mainz, Institut für Soziologie, 55099 Mainz, Germany. E-Mail: schulal@uni-mainz.de

URL: http://www.soziologie.uni-mainz.de/FB02/Hradil/118.php 


\section{Comparative Population Studies - Zeitschrift für Bevölkerungswissenschaft}

wWw.comparativepopulationstudies.de

ISSN: 1869-8980 (Print) - 1869-8999 (Internet)

Published by / Herausgegeben von

Prof. Dr. Norbert F. Schneider

Federal Institute for Population Research

D-65180 Wiesbaden / Germany

Managing Editor /

Verantwortlicher Redakteur

Frank Swiaczny

Assistant Managing Editor /

Stellvertretende Redakteurin

Katrin Schiefer

Language \& Copy Editor (English) /

Lektorat \& Übersetzungen (englisch)

Amelie Franke

Copy Editor (German) /

Lektorat (deutsch)

Dr. Evelyn Grünheid

\section{Layout / Satz}

Beatriz Feiler-Fuchs

E-mail: cpos@bib.bund.de

\author{
Scientific Advisory Board / \\ Wissenschaftlicher Beirat \\ Jürgen Dorbritz (Wiesbaden) \\ Paul Gans (Mannheim) \\ Johannes Huinink (Bremen) \\ Marc Luy (Wien) \\ Clara H. Mulder (Groningen) \\ Notburga Ott (Bochum) \\ Peter Preisendörfer (Mainz)
}

\section{Board of Reviewers / Gutachterbeirat} Martin Abraham (Erlangen)

Laura Bernardi (Lausanne) Hansjörg Bucher (Bonn) Claudia Diehl (Göttingen) Andreas Diekmann (Zürich) Gabriele Doblhammer-Reiter (Rostock) Henriette Engelhardt-Wölfler (Bamberg) E.-Jürgen Flöthmann (Bielefeld) Alexia Fürnkranz-Prskawetz (Wien) Beat Fux (Zürich) Joshua Goldstein (Rostock) Karsten Hank (Köln) Sonja Haug (Regensburg) Franz-Josef Kemper (Berlin) † Michaela Kreyenfeld (Rostock) Aart C. Liefbroer (Den Haag) Kurt Lüscher (Konstanz) Dimiter Philipov (Wien) Tomáš Sobotka (Wien) Heike Trappe (Rostock) 